\title{
A Study of the Restitution Masses formed by the Dissociated Cells of the Hydroids Antennularia ramosa and $A$. antennina.
}

$\mathrm{By}$

\author{
W. De Morgan and the late G. Harold Drew, \\ Beit Memorial Research Fellow,
}

From the Laboratory of the Marine Biological Association at Plymouth.

Figures 1-9 in the Text.

TABLE OF CONTENTS.

Introduction . . . . . . . . . . ${ }_{440}^{\text {PAGE }}$

Methods and Technique . . . . . . . . . . . . . 443

The normal tissues which, after dissociation, give rise to the restitution masses . 445

The process of formation of restitution masses . . . . . . . . 448

The morphology and duration of life of the restitution masses _ . . . 451

The histology of the restitution masses . . . . . . . . . 453

Synopsis of experiments . . . . . . . . . . . . . 458

Summary and conclusion $\quad . \quad$. $\quad . \quad$. $\quad . \quad . \quad . \quad . \quad 462$

\section{INTRODUCTION.}

THE work described in this paper is, in the main, a repetition of that of H. V. Wilson, " On the Behaviour of the Dissociated Cells in Hydroids, Alcyonaria, and Asterias," published in October, 1911, in the Journal of Experimental Zoology. The results he obtained are so far-reaching in their bearing on the present theories of the organization of living matter that his work appeared well worth repeating on species closely allied to those on which he experimented. Our results largely bear out his contentions, though we were not successful in carrying the regenerative process as far as the production of new hydranths, and the histological structure of the restitution masses we obtained differed in many ways from that described in Wilson's paper. These differences are probably due to the fact that we experimented with other species of Hydroids to those used by Wilson : in other respects we have followed his technique and repeated his experiments, and up to a certain point have obtained the same results, and thus it may be considered that we have verified his very remarkable work. 
The especial interest of our investigations lies in the rather anomalous fact that we have not been successful in obtaining regeneration of the complete organism from the dissociated cells. In our experiments the restitution masses, by some rearrangement or metaplastic process taking place among their conglomerated cells, formed tissue aggregates histologically reduplicating the structure of the parent organism, but in a quite irregular and apparently meaningless manner. The masses consisted of irregular convoluted tubules lined with endoderm cells, imbedded in closely packed but irregularly arranged ectoderm cells, among which many isolated endoderm cells were distinguishable, and the whole tissue aggregate was surrounded by a transparent perisarc which it had secreted. Slight contractions and alteration in shape in the cell masses often took place even after several weeks, and many of them remained alive and showed no signs of degeneration for at least fifty days, which was very much longer than the Hydroids themselves could be kept alive under similar conditions.

Before proceeding further it will be as well to briefly summarize the results obtained by $\mathrm{H}$. V. Wilson. The Hydroids on which he experimented were Eudendrium carneum Clarke, and Pennaria tiarella McCrady. Proceeding as described in his paper, he squeezed pieces of the Hydroids through bolting silk of 50 and 75 meshes to the inch and then allowed the dissociated cells to form aggregate masses. The following is an abstract of some of his experiments.

\section{Eudendrium carneum.}

Experiment, July 9. A colony was squeezed, and fusion was observed under the microscope. In a few hours irregular, lobed, flattened masses about $5 \mathrm{~mm}$. wide and $1 \mathrm{~mm}$. thick were formed. By the next day, a perisarc surrounding the whole mass had been secreted. In 4 days outgrowths had formed in which ectoderm and endoderm could be distinguished. Some of the masses died, but others remained alive. These were isolated, and in 24 hours, one projecting outgrowth ended in a hydranth, and a day later two completely formed hydranths were developed from another mass. These hydranths have the characteristic size, shape, and colour of the normal adult polyp.

Experiment, July 14. The tissue died before mass formation.

Experiment, July 15. Flattened plasmodial masses and lumps were formed, but soon died. 
Experiment, July 18. Tissue died.

Experiment, July 19. Tissue formed, but died next day.

Experiment, July 22. Tissue died next day.

Experiment, July 23. Tissue died next day.

Experiment, July 25. Small masses of tissues were formed, and secreted perisarc. They were alive 4 days after formation.

Experiment, July 27. Most of the large pieces of tissue died, but small lumps were alive 4 days later, and cœnosarcal outgrowths had sprouted.

Experiment, August 1. Small masses a fraction of a millimetre lived, showed perisare and were alive 2 days later.

Experiment, August 2. (a) Most of the tissue formed was alive on August 3rd; much died by 7 th. Outgrowths were formed, with vertical branches by 11th, but were sickly.

Experiment, August 2. (b) Many small spheroidal masses formed, and developed perisarc, but not cœnosarcal outgrowths. They were alive 5 days later.

\section{Pennaria tiarella.}

Experiment, July 26. Cell fusion and aggregation commenced at once. Small masses formed in an hour, and fused into tissue. In about 4 hours masses $1 \mathrm{~mm}$. in diameter have formed. Next day perisarc formed, and in 3 days outgrowths were developed, but at the same time many of the larger masses died. In 5 days hydranths appeared on the outgrowths with characteristic tentacles.

Experiment, August 3. In this experiment only stem material was used. Fusion was rapid, and in about an hour a cake was formed. Next day perisare appeared, and outgrowths commenced. Another mass from this culture in two days developed a hydranth. In 5 days all masses of this experiment except 4 were dead; the survivors developed outgrowths and were then preserved.

Many other valuable observations are included in Wilson's paper, but these experiments are the only ones with which we are immediately concerned. The paper also contains a full account of the literature on the subject of the behaviour and the regenerative properties of dissociated somatic cells of various species of animals, and accordingly a review of this literature will not be repeated here. 
It is noteworthy that in Wilson's experiments the restitution masses which did not develop so far as to produce hydranths in every case died within a few days, while in our experiments, though none of the restitution masses produced hydranths, yet many of them remained alive for at least 60 days. Wilson does not state how long the masses which gave rise to hydranths in his experiments remained alive.

\section{METHODS AND TECHNIQUE.}

The species used by Wilson at Beaufort N.C., U.S.A., were not available at Plymouth. The species on which most of our experiments were carried out were Antennularia ramosa and Antennularia antennina. Species of Tubularia, Plumularia, and Clava were also tried, but did not give satisfactory results; though many of these produced restitution masses from their dissociated cells, yet these masses did not remain alive for more than a few days, and accordingly Antennularia ramosa or $A$. antennina were used in all our later experiments.

All material was obtained from Plymouth Sound, inside the Breakwater.

The method of obtaining the isolated cells was the same as that employed by Wilson. Squares of bolting silk of 50, 75, and 180 meshes to the inch were thoroughly washed and finally rinsed out in boiling water. A good sized colony of Antennularia was then cut up into small pieces about a quarter of an inch long and these pieces were laid in a heap in the middle of a square of bolting silk, which was then folded over so as to make a small bag containing the fragments of the Hydroid. This bag was then squeezed with a pair of wooden forceps into a watchglass containing a little sea-water. With a quite moderate degree of pressure the body cells of the Hydroid are forced out of the cut ends of their protecting tubes of perisarc and then through the meshes of the bolting silk, and by this process become separated into isolated cells or small cell aggregates which collect as an even layer at the bottom of the watch-glass. It is necessary that a sufficient amount of material should be used to form a complete layer of isolated cells at the bottom of the watch-glass about $1 \mathrm{~mm}$. thick, if the formation of restitution masses that will show any degree of subsequent development is required.

The watch-glasses containing the isolated cells were slightly shaken and rotated so as to bring the cells together as much as possible, and then when they had aggregated to some little degree the watch-glass was immersed in a finger-bowl of sea-water. It was found advisable to place 
the finger-bowls in troughs of running water in order to keep them cool and at a more or less constant temperature; before this was done a very large mortality among the restitution masses occurred even under the most favourable conditions, and it would seem that the temperature of the laboratory, which is heated by hot water, was too high for these unless some artificial method of cooling was employed.

Two kinds of water were used in the experiments : (1) that brought from outside the Plymouth Breakwater, and (2) water circulating in the Laboratory tanks, treated with animal charcoal and passed through a Berkefeld filter as described by Allen and Nelson (see Journal of Marine Biological Association, Vol. VIII, p. 43\%). It proved, however, immaterial which kind of water was used. For the first day or two the water of the cultures was changed frequently with a view to keep down the infusoria and flagellates as much as possible; but it is impossible to banish them altogether, and as soon as a perisarc was well established round the masses they were immune to attacks of protozoa. After this time the culture water was not changed oftener than once a week. Possibly the flagellates developed more quickly in the Berkefeld than in the outside water.

It was found advisable to utilize the colonies of Antennularia immediately after they were brought in, as by this means more vigorous restitution masses were obtained. If the colonies were kept over night in the ordinary tank water, in the filtered Berkefeld water, in water collected from outside the Breakwater, satisfactory results were not obtained. In one experiment, however, excellent results were obtained from a colony of $A$. antennina, which had lain for some weeks in a laboratory tank. The comparative greater longevity and vitality under Laboratory conditions of the restitution masses compared to the original colonies is very curious and difficult to explain.

The changes in shape and other general external developments of the restitution masses were noted by frequently drawing under a camera lucida: for this purpose the watch-glasses containing the cultures were simply removed from the finger-bowls and placed on the stage of the microscope ; after drawing they were returned to the finger-bowls without disturbing the cultures.

When required for histological examination, the restitution masses were fixed in Flemming's fluid (strong formula). Ten minutes fixation was found to be long enough for a moderate sized mass, say about the size of a grain of barley; if fixed for longer periods the cells showed a tendency to become "osmicated" and stained badly. After fixing they 
were washed for a few minutes in water, passed quickly up through the alcohols to $70 \%$, and then washed for some hours in $70 \%$ alcohol, containing a little hydrogen peroxide. After dehydration they were embedded in paraffin and cut into sections $5 \mu$ thick. Heidenheim's Iron Alum Hæmatoxylin, followed by Lichtgrün F.S. in $70 \%$ alcohol proved a satisfactory stain for general purposes.

Small restitution masses which were difficult to handle were sectionized after previously mounting on a piece of amyloid liver, the mass being made to adhere to the surface of the liver by means of a little albumen, which was subsequently coagulated by alcohol.

\section{THE NORMAL TISSUES WHICH, AFTER DISSOCIATION, GIVE RISE TO THE RESTITUTION MASSES.}

Antennularia ramosa is one of the Plumulariidæ. It consists of shoots which, springing from a single trunk at a certain height, divide and subdivide : the stems are thick and their branchlets are long and tapering, having their internodes of equal length. The branchlets are closely set and arranged in whorls where they come off the parent stem. The Hydrothecæ are small and campanulate in shape. Nematocysts are present. The Gonothecæ are pear-shaped and single; and have a subterminal aperture facing towards the stem. In healthy specimens the perisarc is transparent and colourless, and the coenosare is of a light yellowish green tinge.

Antennularia antennina consists of clustered stems, simple or slightly branched, springing from a sponge-like mass of interlacing fibres. The branchlets are short, swollen at the base, arranged in a whorl on each articulation of the stem. They are divided by oblique joints into internodes, which are alternately larger and smaller, the former bearing the hydrothecæ. The hydrothecæ are small and campanulate in shape. The Gonothecæ are produced singly in the axils of the branchlets; they are oval, with a subterminal aperture looking towards the main stem. The perisarc is transparent and colourless, and the cœnosarc of a somewhat brighter yellow colour than in the case of Antennularia ramosa.

The cœnosarc of both species is hollow, and consists of a tube of cellular tissue in the walls of which a number of smaller tubes run in the direction of the long axis of the stem. These smaller tubes are the direct continuations of the enteric cavities of the individual hydranths, and are lined with cells of a type similar to those forming the hydranths. The whole arrangement is suggestive of that in a young dicotyledonous 
plant having a hollow stem, the enteric cavities lined with the endoderm cells of the individual hydranths corresponding to the vascular bundles of the plant.

A view of a cross section through a stem of Antennularia ramosa is shown in Fig. 1. Externally it is limited by the structureless perisarc,

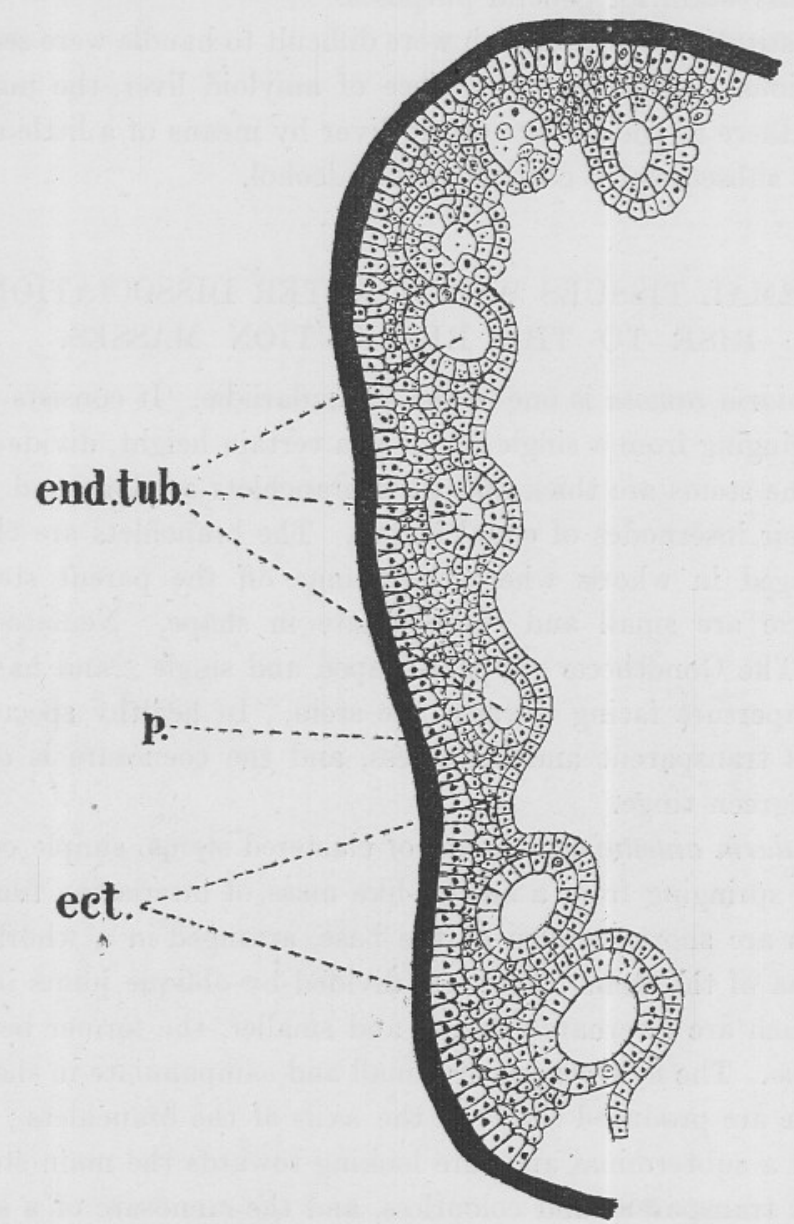

FIG. 1. $\times$ 175.-Section of portion of normal cœnosare, showing cœnosarcal continuations of tubules continous with the enteron of individual polyps. End. tub., endoderm tubules; $p$., perisare ; ect., ectoderm cells.

within this is a somewhat indefinitely arranged mass of slightly elongated cells with small but sharply staining nuclei; of these the cells in immediate contact with the perisarc are larger than the others, which appear to be tightly packed together. At regular intervals within this 
cell mass tubules lined with large columnar endoderm cells can be seen, and these tubules are covered on the side where they project somewhat into the hollow cavity of the stem with a single layer of small cubical cells, which form a complete inner lining to the hollow stem. In longitudinal sections the tubules can be traced up into the individual polyps, and it can readily be seen that their cells are directly continuous with the endoderm cells lining the enteric cavity of the polyps. Similarly the smaller cells in which these tubules are embedded in the coenosare can be seen to be directly continuous with the ectoderm cells of the polyps. Neither in sections of the cœnosare nor of the polyps were we able to distinguish any structure or structureless layer corresponding to the mesoglæa.

In Fig. 2 a tubule with surrounding ectoderm cells is shown under a higher power of magnification. It will be noticed that the endoderm

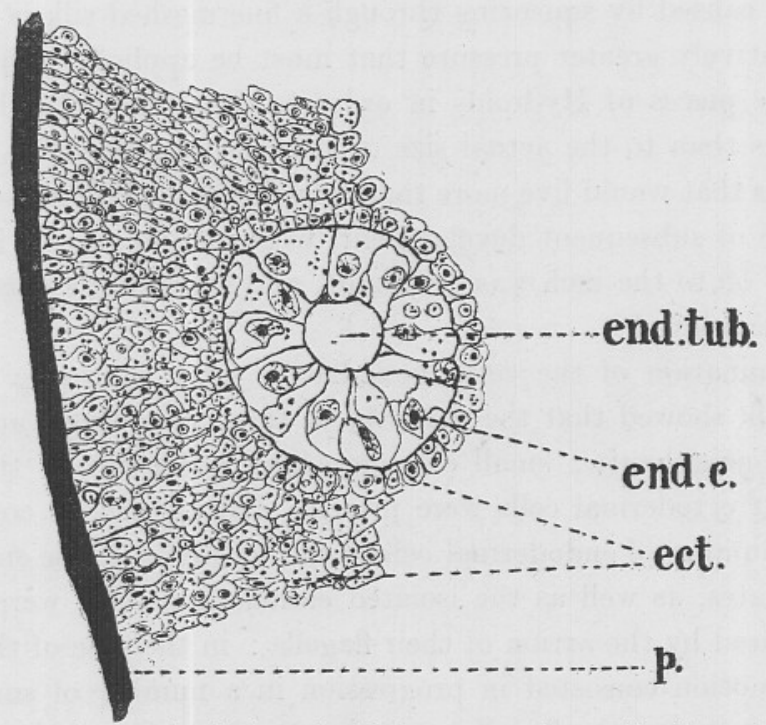

Fic. 2. $\times 500 .-$ A normal tubule under higher power of magnification. Ect., ectoderm cells; end. c., endoderm cells; end. tub., endoderm tubules; p., perisare.

cells are distinctly columnar, with broad bases, and that they are considerably larger than the ectoderm cells. Their nuclei are relatively large, and usually situated near the base of the cell : the nuclear membrane is sharp and well defined and the nucleoli are remarkably distinct; strands of chromatin are present, radiating from the nucleolus towards the nuclear membrane. The cytoplasm is distinctly granular, and frequently darkly staining vacuoles, presumably food vacuoles, were seen. Flagella do not appear to be present on these $\mathrm{c} x$ nosarcal endoderm cells. 
The smaller ectoderm cells are slightly elongated, often with pointed ends, with the exception of those forming the layer lining the hollow of the $\mathrm{c} x$ nosare, which are almost cubical in shape. The nuclei are small, and the nucleoli relatively large and distinct.

Other structures such as the germ cells, nematocysts, etc., are not described here as they appear to merely play the part of foreign bodies in the restitution masses, and do not enter into their development.

\section{THE PROCESS OF FORMATION OF RESTITUTION MASSES.}

The cells that are obtained after squeezing through bolting silk of 50 meshes to the inch are, many of them, comparatively little damaged; but if a finer silk is employed, such as that having 180 meshes to the inch, the majority of the cells are crushed and broken. It would appear that the injury caused by squeezing through a fine meshed silk is due rather to the relatively greater pressure that must be applied to the bag containing the pieces of Hydroids in order to drive the cells through the fine meshes than to the actual size of the meshes themselves. Restitution masses that would live more than a few days, and which would show any degree of subsequent development, were not obtained when a finer mesh than 50 to the inch was employed, and accordingly this was most generally employed.

An examination of the cells immediately after squeezing through a 50 -mesh silk showed that the majority of them were single and isolated from their neighbours; small cell aggregates consisting at the most of six or eight ectodermal cells were present, and aggregates consisting of a smaller number of endodermal cells could be seen. These endodermalcell aggregates, as well as the isolated endodermal cells, were in active motion caused by the action of their flagella : in the case of the isolated cells this motion consisted in progression in a number of small spirals due to the fact that the flagella are only attached to one side of the cell.

In addition to the comparatively uninjured cells and cell aggregates, a good deal of granular debris was present, and minute rounded bodies which were presumably small protoplasmic masses produced by the disintegration of cells which had been actually crushed in the squeezing process. Many nematocysts, some with their threads ejected, could also be seen, and ova were often present. In some cases small pieces of the tentacles accidentally were forced through the meshes of the silk intact; but these were usually visible to the naked eye, or under a low power of magnification, and when seen were removed with fine-pointed forceps. 
If such pieces of tentacle were not removed, and became included in the restitution masses, it was noticed that they soon degenerate and

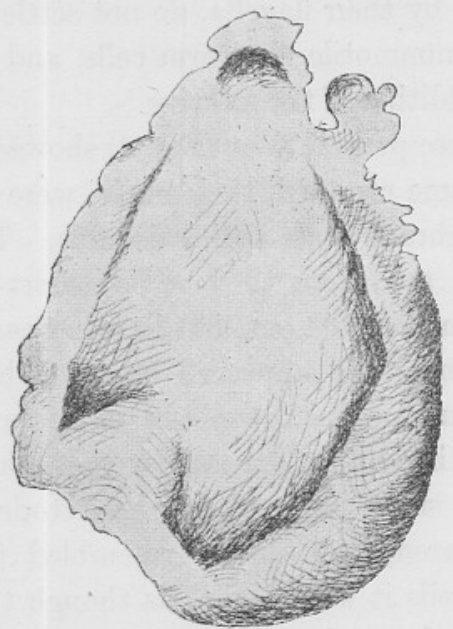

Fig. 3. $\times 16 .-$ A restitution mass 48 hours old, showing curling up of edges.

never show any sign of regeneration, and in this our observations agree with Wilson's.

Preparations of the freshly squeezed cells were made by fixing on a

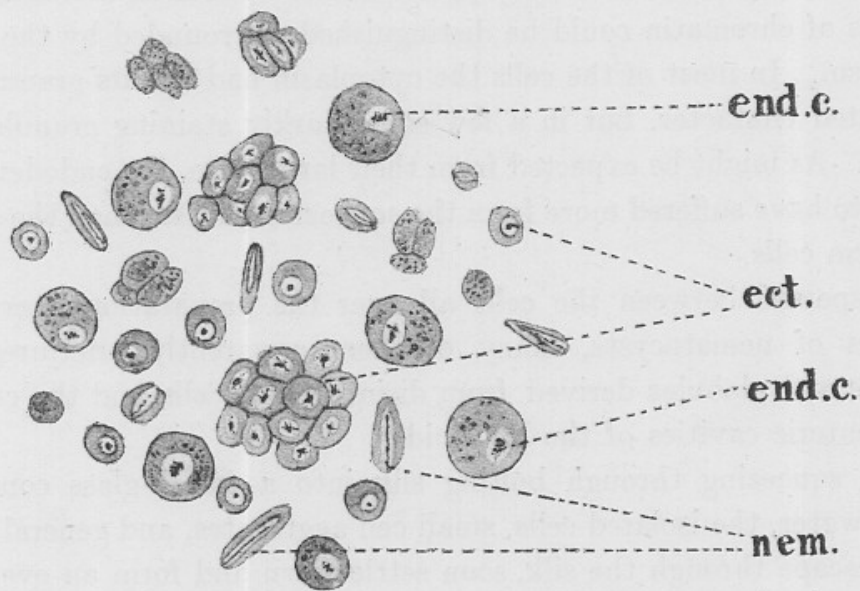

Fic. 4. $\times 500$.-Isolated cells, after squeezing through bolting silk of 50 mesh. Ect., ectoderm cells ; end. c., endoderm cells; nem., nematocyst.

slide with Acetic Sublimate Solution, and subsequent staining with Heidenheim's Iron Hæmatoxylin, followed by Lichtgrün F.S. (Fig. 4). In such preparations both the ectodermal and endodermal cells were easily recognizable, though the proportion of endodermal cells was

NEW SERIES.-VOL. X. NO. 3. оCTOBER, 1914. 
comparatively small compared to the number seen in unfixed preparations. This was probably due to the fact that the endodermal cells, being kept in motion by their flagella, do not settle down on the surface of the glass like the nonmotile ectoderm cells, and consequently do not adhere to it on the addition of the fixative.

Examination of these preparations (Fig. 4) showed that the ectodermal cells had mostly become rounded, their nuclei were somewhat indistinct, and no nuclear membrane was distinguishable. The nucleoli in some cases stained darkly, and from them a few short radiating strands of chromatin could often be made out, but in other cases the whole nuclear structure stained faintly and appeared as a roughly spherical mass of indeterminate structure. The cytoplasm of these cells was clear, the periphery often staining somewhat darker than the more central part. Where occurring in small aggregates, the ectodermal cells appeared comparatively uninjured, and closely resembled the normal. In the case of the isolated cells it would seem as though the pressure to which they had been exposed had burst the nuclear membrane and caused a fusion of the nucleoplasm and cytoplasm.

The larger endodermal cells in these fixed preparations had lost their columnar shape and become rounded, and their flagella were not seen. The nuclei were indistinct and appeared as a light area in which a few granules of chromatin could be distinguished, surrounded by the darker cytoplasm. In most of the cells the cytoplasm had lost its granular and vacuolated character, but in a few some darkly staining granules were present. As might be expected from their larger size, the endoderm cells appear to have suffered more from the squeezing process than the smaller endoderm cells.

Interspersed between the cells all over the preparations were large numbers of nematocysts, many of them apparently uninjured, and granules and globules derived from disintegrated cells and the contents of the enteric cavities of the Hydroids.

After squeezing through bolting silk into a watch-glass containing a little water, the isolated cells, small cell aggregates, and general debris, which escape through the silk, soon settle down and form an even layer of a greyish yellow colour over the bottom of the watch-glass. Within two or three hours this layer shows a tendency to subdivide into a number of small nodules, and after the lapse of another hour these nodules are usually distinct elevated aggregations, often connected with one another by fine strands which gradually become thinner and contract until they are absorbed into the nodules from which they radiated. If left undis- 
turbed, there seems to be no tendency for these nodules to change their position, but if they are disturbed by shaking or rotating the watchglass so that they are brought into contact with one another they mutually adhere, and in the course of some hours may give rise to one or more large restitution masses in which no trace of the smaller nodules originally formed can be distinguished.

Similarly if the watch-glass, immediately after the cells have been squeezed into it, be rotated so that all the cells form a compact heap in the centre, the restitution masses may be formed as one or more thick flat cakes with rounded edges without the preliminary formation of the smaller nodules described above.

\section{THE MORPHOLOGY AND DURATION OF LIFE OF THE RESTITUTION MASSES.}

The after history of a restitution mass depends very much on its original size when first formed, and this again depends on whether the dissociated cells were shaken together or allowed to form the small nodular masses already described.

When one of these larger masses of tissue is first formed it consists

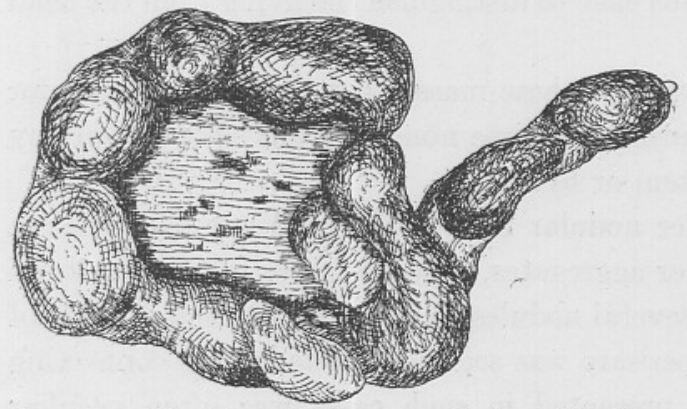

FIG. 5. $\times 16$. - A restitution mass 8 days old, showing curling up and nodulation of edges.

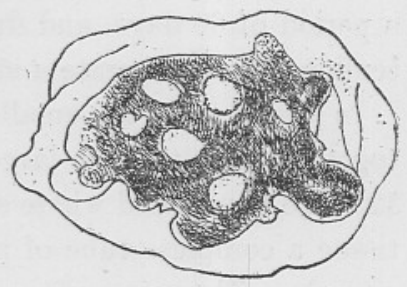

FIG. 6. $\times 16 .-\mathrm{A}$ restitution mass 34 days old, showing well-marked shrinkage away from the perisarc and fenestrated appearance of the cell mass.

of a flat cake of tissue of irregular shape, sometimes adherent to the glass. During the first 12 hours after its formation, a considerable amount of alteration in shape occurs, the edges of the mass turn up away from the glass, and a good deal of retraction takes place and consequently the tissue becomes stronger and more compact. After from 12 to 18 hours a delicate, transparent, colourless membrane is secreted round the mass, completely enclosing it and forming a tough protecting layer : this layer 
is evidently similar to the perisare of the normal animal. Once this perisare has been secreted, the restitution mass appears to be immune to the attacks of flagellates or bacteria, which are unable to penetrate it. From this stage onwards the external changes that occur take place slowly. The turned-up edges become thicker and more nodulated at the expense of the central part, and sometimes may project in the form of spherical or ovoid nodules connected at the base with the main mass by a comparatively small isthmus of tissue. (In Fig. 3 a mass, 48 hours old, is shown, and in Fig. 5 one of 8 days.) There is later a slow but continuous shrinkage of the restitution mass away from its perisare, leaving a clear space between the two (Fig. 6), after from three to four weeks irregularly circular spaces begin to show in the cell mass, which then presents a somewhat sponge-like fenestrated appearance (Fig. 6). Later changes are extremely slow, and consist of a further slight shrinkage, and increase in size of the spaces in the tissue. During all this time the restitution mass retains its yellowish colour and definite outlines, and sections show that the cells are healthy and undegenerated : in the case of masses that die, the yellowish colour is rapidly lost, and they appear as dirty white, soft, floccular bodies, which soon fall a prey to bacteria and other parasites ; it is thus easy to distinguish the living from the dead masses by the eye.

At the time of writing some of these masses have been kept alive for a period of 60 days, and during this time none of them have shown any tendency to regenerate a stem or hydranth.

In the case of the smaller nodular masses that had not been shaken together so as to form larger aggregates, a perisarc was secreted in from 12 to 18 hours, and where several nodules were joined by their strands of tissue a complete tube of perisare was secreted around these connecting strands. The appearance presented in such cases was often peculiar and somewhat suggested an attempt at the formation of hydranths which had aborted through not being able to burst the surrounding perisarc; but observations made from the earliest stages, when the nodules arose from simple aggregations of the cells show that there is no justification for such a view, and this was borne out by the internal structure of these nodules as shown in sections of fixed preparations. When the process of contraction of the restitution masses had proceeded a little further, the connecting strands of tissue between individual nodules were often completely retracted, thus leaving the nodules merely connected by empty tubes of transparent perisarc. 


\section{THE HISTOLOGY OF THE RESTITUTION MASSES.}

Our observations on the histology of the young restitution masses agree closely with those of Wilson, so that it is not necessary for us to describe the younger stages in great detail.

A section of a young restitution mass from 18 to 24 hours old shows that a perisarc has been secreted, and that it is still in close contact with the cell mass. The central cells are irregular, and show no trace of stratification : the ectoderm and endoderm cells can be recognized, and present a similar appearance to that described as seen in preparations of the freshly squeezed cells, with the exception that the endoderm elements were even less definite, contained no granules and were distinguishable in relatively small numbers: a few of the cells retained their definite outlines, but others were less distinct and appeared to join up with their neighbours by means of pseudopodia-like processes. It would seem probable, as Wilson suggests, that the structure throughout is that of a cellular syncytium, and that even where the cells appear distinct they are united by protoplasmic strands. He also remarks that the endoderm cells form only a small fraction of the syncytium, though they composed a very large part of the mass when fusion began. This he explains by considering that the endoderm cells undergo a transformation which effectually precludes their recognition later, and we would suggest that the majority of these cells take on a plasmodial character, and so by forming a protoplasmic reticulum unite and draw together the other elements of the mass.

The peripheral cells in contact with the perisarc in these young restitution masses take on an epithelial character quite early, as might be expected from the fact that they have secreted the perisarc. They are distinguishable as a layer of cells resembling those forming the normal ectoderm, with flattened bases in even contact with the perisarc, and they are recognizable several days before any other rearrangement of the cells is apparent in the mass.

A comparison between sections of early and later stages shows that the nematocysts included in the masses gradually disappear and take no part in the further development. A similar observation has been made by Wilson.

Sections after 6 days (Fig. 7 ) show that the cells are much more definite, the individual cell walls show clearly and the nuclei of the ectoderm cells stain distinctly; the mass has largely lost its plasmodial indefinite character, much of the cell debris has disappeared and the nematocysts 
are not present or are not recognizable, and have probably been dissolved away. Some irregular darkly staining masses suggestive of endodermal cells are present, but they are somewhat indefinite. The more distinct ectoderm cells are often arranged in whorls or rows, and

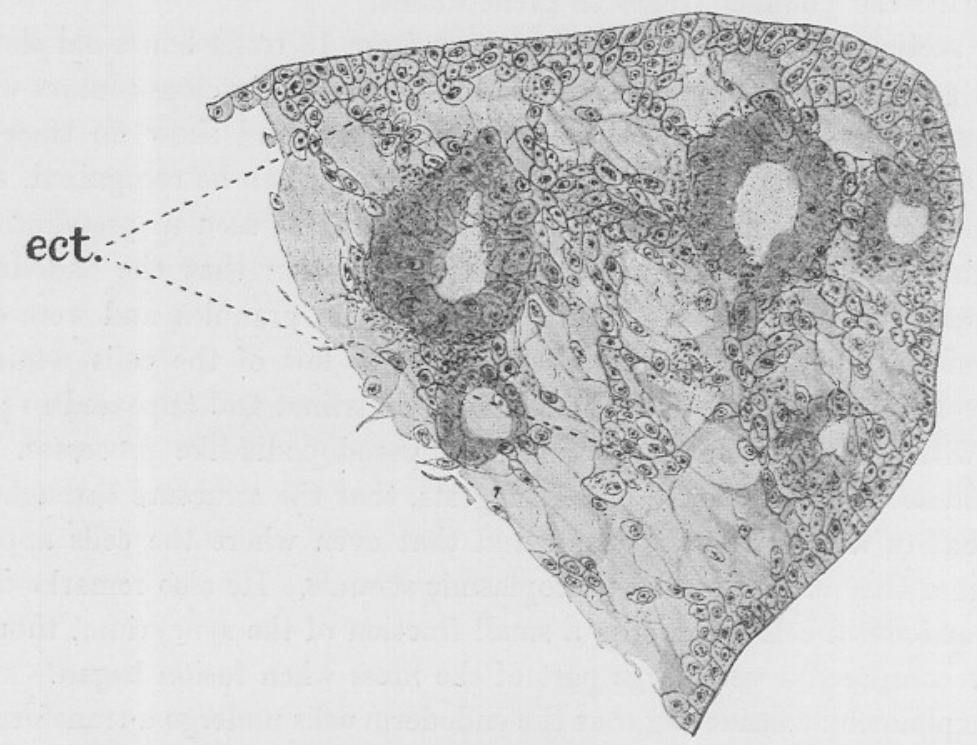

Fig. 7. $\times 260$. - Section through part of a restitution mass 6 days old, showing indefinite arrangement of cells. The ectodermal cells are fairly well differentiated; but the endodermal elements, though showing a tendency towards tubule formation, are not?well defined. The perisare is not shown. Ect., ectoderm cells.

the external layer which secreted the perisarc is well defined. The impression conveyed by examination of sections at this stage is that some process of rearrangement has been initiated among the cells, but there is little to show what may be expected to be the result of this rearrangement. No mitoses were observed.

Seven days later development has proceeded much further, many cells definitely of the endodermal type are present, and they contain numbers of small granules in their cytoplasm. These cells are often arranged so as to form distinct tubules, each having a definite lumen and closely resembling in structure the cœnosarcal part of the enteron of an individual polyp. In other places the endodermal cells are arranged in rows, in irregular masses, or singly, embedded among the ectodermal cells. Where formed, the tubules are always in any one section cut transversely, longitudinally, and at intermediate angles, hence they must be irregularly coiled and crossed within the mass. At this stage the ectodermal cells 
are sharp and distinct, approximating the normal in size but slightly larger; they have a tendency to be fusiform in shape with sharply pointed extremities, and are often joined end to end. Spaces between the cells are frequent, but they are occasionally found arranged in compact whorls or masses. The outline of the cells is well defined, the cytoplasm clear but slightly vacuolated, the nuclear membrane and nucleolus distinct.

Sections of restitution masses at the end of 3 weeks (Fig. 8) showed a still more definite arrangement of convoluted endodermal

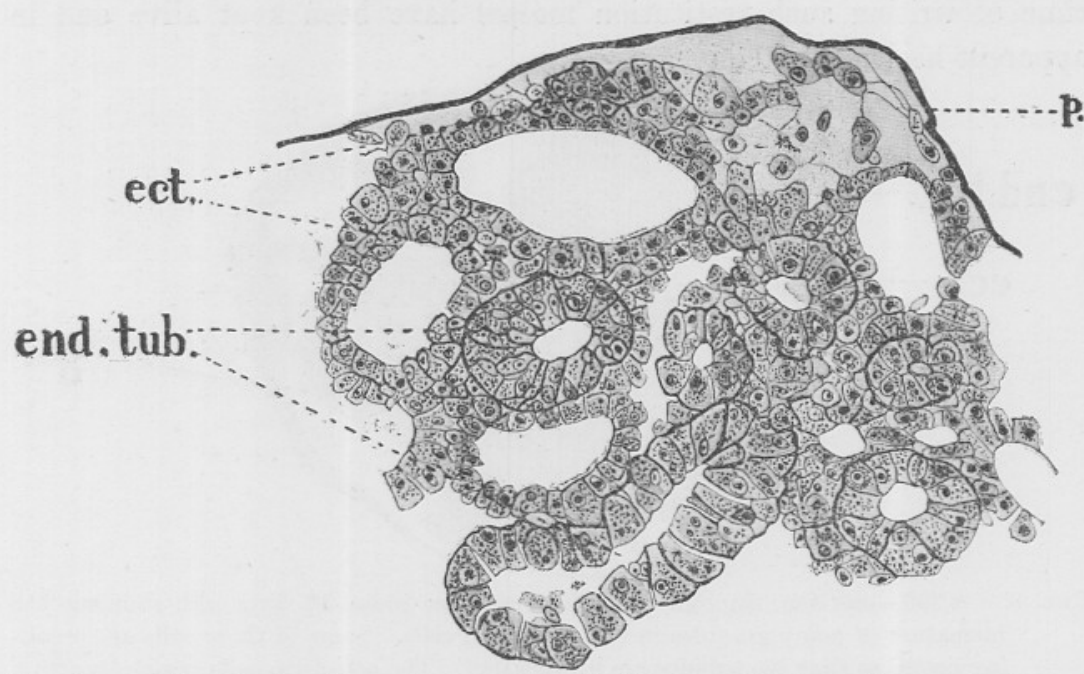

FIG. 8. $\times 260$. - Section through part of a restitution mass 20 days old, showing formation of definite endodermal tubules; all the cells in the mass are sharp and well defined, and the plasmodial character noticeable in earlier stages is lost. Ect., ectoderm cells; end. tub., endoderm tubules; $p$., perisarc.

tubules. The cells forming these tubules were regularly arranged and closely resembled those lining the enteric cavity of the normal polyp with the exception that no flagella were seen. The cytoplasm of these cells was crowded with large granules, which were often so plentiful as to partially obscure the nucleus. The ectoderm cells were present in even smaller numbers than in earlier stages, but were very definite in structure. Occasional large spaces, corresponding to the spaces producing the fenestrated appearance described as occurring in older masses, were seen among the cells, and other areas in which the cells had degenerated and left merely some granular debris were observed.

At the end of 5 weeks (Fig. 9) the endodermal cells forming the tubules had become crowded with darkly staining spherical granules of 
varying size, often totally obscuring the nucleus, and the ectoderm cells often partially or completely surrounded the tubules in the form of a well-defined single cell layer. In some cases the cells of the tubules had apparently undergone autolysis, and a space containing a little granular cell debris was left surrounded by the ectodermal layer.

Later the stages show little change or further degeneration. Sections after 50 days show that a large proportion of the endodermal cells are crowded with granules, and many of the tubules have disappeared; on the other hand, the ectoderm cells are quite undegenerated. At the time of writing such restitution masses have been kept alive and in apparent health for 60 days.

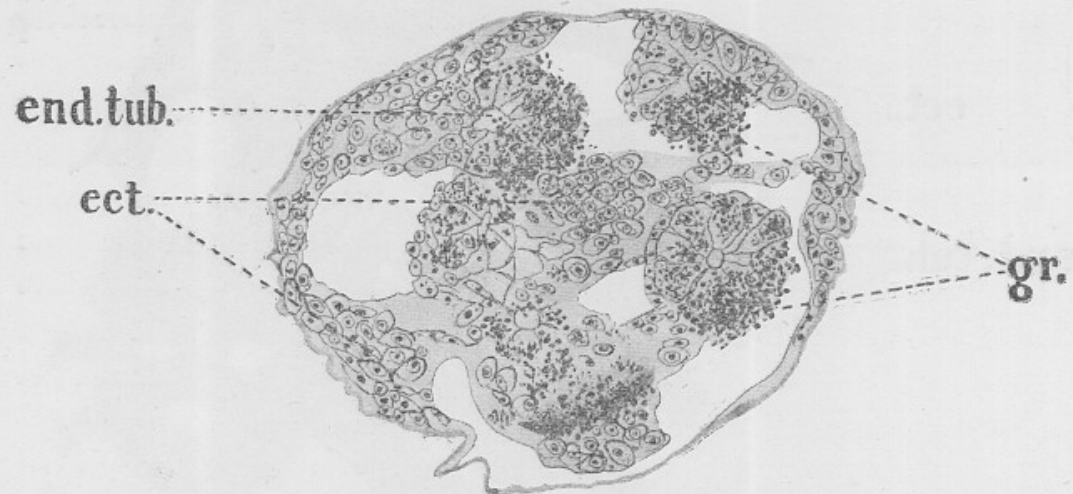

Frg. 9. $\times 260$.- Section through a small restitution mass 35 days old, showing the formation of many granules in the endoderm cells. Some of these cells are breaking down, so that the tubules are less distinct. The ectoderm cells remain'healthy. Ect., ectoderm cells ; end. tub., endoderm tubules; gr., cytoplasmic granules.

No signs of mitosis or any form of cell division was observed in any stage.

We would suggest that the changes that take place may be explained as follows :-

The endoderm cells are considerably more damaged in the process of squeezing through the bolting silk than the smaller and tougher ectoderm cells. They lose the majority of their cytoplasmic granules, which are probably in the nature of a digestive ferment, and the nuclear membrane is usually ruptured, causing certain changes in the nuclear structure. As the cells begin to form aggregates the endoderm cells become diffuse and join with each other by means of protoplasmic processes to form a plasmodium, in the midst of which the comparatively uninjured ectoderm cells are embedded. Certain ectoderm cells make their way towards the periphery of the mass, or are left there by the 
contraction of the plasmodium away from them, and secrete a perisarc within 12 or 18 hours. This resumption of function in so short a time and the localization of the secreting power so that secretion of perisare takes place only on the outside of the mass, is somewhat remarkable, considering that all the normal relationships between the cells must have been completely upset. Contraction of the plasmodium of endoderm cells still continues, eventually causing the mass to contract away from the perisarc, and it is noteworthy that when this occurs no fresh perisare is secreted by the peripheral cells. If, however, a small piece of the perisarc is removed, it is rapidly re-secreted by the cells in the neighbourhood, and the gap is healed. From this it would seem possible that the secretion of perisarc is a direct reaction of the ectoderm cells when in contact with sea-water, and that it is not produced when they are in contact with the fluid filling the space between the shrunken mass and the perisarc, and that accordingly this fluid has a different constitution to sea-water.

During the retraction of the plasmodium, the endodermal cells gather together their ramifying processes and again become differentiated, and so very slowly resume their normal form. Of the manner in which many of them become collected so as to form definite tubules, we are unable to offer any explanation. The appearance of sections at a period when the earliest stages of tubule formation are apparent suggests that the plasmodial masses, which will later develop into endodermal tubules, become arranged and segregated before they have differentiated into recognizable endoderm cells, but this is the merest surmise. In cases like this, where individual cells cannot be watched through their modifications and development, the value of the evidence of sections of different masses is always doubtful. Considering that no sign of cell division was ever seen in our experiments it would seem strongly probable that a certain amount of actual migration and rearrangement of the cells within the masses must occur, but no clue is given as to the form or mode of action of the forces causing this rearrangement. As in the case of Wilson's experiments, however, it is difficult to imagine any "form regulation " force coming into play after isolation and subsequent agglomeration of the individual cells forming the original organism.

We consider that the granules found in the cytoplasm of the endodermal cells in the older restitution masses are probably in the nature of the proenzyme of the digestive ferment. Since the tubules are closed, and there is no food stimulus, the granules are not discharged, but accumulate in the cell up to a certain limit; when this is reached the cell ruptures and autolysis ensues. From the fact that these granules are formed, it 
follows that a certain amount of active metabolism is going on within the mass, and from the disappearance of the cell debris, nematocysts, ova, etc., which are included in the restitution masses when first formed, it would seem at least possible that these may be absorbed and used up in the metabolic processes of the living cells. Similarly the living cells may feed on those which degenerate.

\section{SYNOPSIS OF EXPERIMENTS.}

Numbers omitted belong to experiments not dealt with in this paper.

Experiment 1.-A colony of Antennularia antennina dredged on 5th December, 1911, was allowed to stand through the night in " outside "water, and at 10 a.m. on 6th was squeezed into watch-glasses containing a little Berkefeld water, through 50 mesh bolting silk.

Aggregation commenced about 12 noon, and the watch-glasses were then placed in finger-bowls of Berkefeld water. Under the microscope no direct motion of the cells towards one another was noticeable. The cells gravitated downwards and adhered together to form small spherical nodules. These were shaken towards the centre of the watch-glass and left for the night.

On the morning of the 7th nearly all the stuff had united to form irregularly shaped plates from 1 to $2 \mathrm{~mm}$. in length connected by narrow strands. In various spots there were club-headed vertical upgrowths from the plates. The whole aggregate, which was greenish yellow in colour, was surrounded with a tough perisarc, no space appearing between it and the contents.

By the 8th considerable contraction of the interior mass was noticed. There was a clear space between the perisare and the contained matter, and clear spots were seen here and there in the plates. The contents of the club-headed upgrowths also contracted.

On the 9th these cultures were found swarming with Infusoria and Flagellates, and they were fixed in Corr. Sub. It was thought then that Protozoa would injure the culture; experience proved that they are not harmful.

Experiment 3.-Colonies of Antennularia antennina collected on 12th December, 1911, and kept 24 hours in Berkefeld water. Squeezed through 180 mesh bolting silk, 11 a.m., December. 13th. By 3 p.m. small spherical masses had formed. On the 14th no change had occurred, the small spheres forming a film over the bottom of the watch-glass. Microscopical examination showed cells with a broken outline ; and small 
fragments, which might be portions of larger cells. This may very possibly result from pressure through such a small mesh as 180 . This experiment gave no further results.

Experiment 4.-14th December. Squeezed a colony of Antennularia antennina that had lain for some weeks in a wooden tank in the Laboratory, through 50 mesh. No attempt at aggregation. Very probably the material had deteriorated.

Experiment 5.-19th December, 1911. Colonies of Antennularia antennina brought in from the Sound. Very dirty, and placed for the night in Berkefeld water. On 20th noon squeezed through 50-mesh bolting silk into watch-glasses. By 4.30 p.m. small masses had formed, mostly vertical to the bottom of the glass, but so far the cells not very coherent. By noon on the 21st numerous small masses surrounded with perisarc adherent to the glass.

Many of these masses gradually died off, without showing any marked change in shape. The contents, however, gradually contracted away from the perisarc, and finally died. Two small masses were alive on 20th January, 1912, 34 days from the commencement of the experiment. These were fixed for sectioning.

Experiment 8.-28th December. Colony of Antennularia ramosa squeezed through 50 mesh at 5 p.m. into outside water. By 11 a.m., 29th, many large masses formed, and adhering to the glass. On 30th the perisarc clearly defined, and the interior plasm slightly contracted away from it. These masses lived until 5th January, 1912, when they died.

Experiment 10.-12th January, 1912, 4 p.m. A very fine colony of Antennularia ramosa squeezed through 50 mesh into watch-glasses which were placed in bowls of outside water. A larger amount of material was used in this and subsequent cultures.

By 13th three large masses, between 3 and $4 \mathrm{~mm}$. in length, had formed. They had not adhered to the glass, and the edges were rounded and turned over, somewhat resembling the helix of the human ear. The surface smooth, showing that perisare had formed, and colour the characteristic yellowish green.

As time went on there was considerable contraction, and the edges became thicker. The cells appeared to migrate from the centre towards the edges, so leaving a thin central nearly clear plate, surrounded by thickened ridges. There was no sign of proliferation or budding of any kind, and by the 24th all three had lost the yellow colour, and looked grey and unhealthy. They were then fixed. 
Experiment 13.-17th January, 1912, 4. p.m. Flourishing colony of Antennularia ramosa squeezed through 50 mesh and 180 mesh into watchglasses. Allowed to settle for 3 hours, and then transferred to bowls of Berkefeld water.

18th, 10 a.m. All the 50-mesh cultures show typical lobate masses, but of smaller size than in Exp. 10. The masses from 180 mesh are smaller and lighter coloured. Pieces of tentacle and theca were observed, and removed. Small masses from each culture placed in finger-bowls containing about 450 c.c. Berkefeld water.

19th. All masses from 50 mesh have contracted greatly, and increased in length vertically. They are generally conical. In places the perisarc not formed. Colour, a healthy yellow. All adhered to the glass.

The culture from 180 mesh differs from above. Only small spherical masses have resulted, generally adhering to the glass. Perisare has not yet been formed.

20th. Most of the masses have contracted further, but the majority are grey and unhealthy looking.

It may be noted that the Laboratory was particularly warm at this time, and the cultures were affected thereby.

24th. Most of the masses were dead, one or two remained alive until 31st. They showed no great change except contraction of the interior protoplasm away from the perisare and slight attempts to form knobs or proliferations. These did not advance far, and the plasm soon contracted away from the surrounding perisarc. Certain of the masses were fixed for examination.

Experiment 15.-25th January, 1912. Antennularia ramosa squeezed through 50 mesh and Antennularia antennina through 180 mesh. Allowed to settle through the day.

26th. The 180-mesh culture has simply formed a film over the bottom of the glass-no masses have formed.

Numerous yellowish masses in the 50-mesh culture. Certain of these were transferred to finger-bowls of " outside" water. Generally they were not healthy in appearance, and a good deal of foreign matter was mixed with them.

28th. One mass remains healthy. Several lobes appear on it. The perisarc has formed, but is rougher than usual. A great many Infusoria in the cultures.

29th. The lobes have contracted into the main mass, which has also further contracted. 
1st February. Still healthy in appearance. The contents have further contracted away from the perisarc. Fixed for examination.

Experiment 17.-31st January, 1912, noon. Squeezed colonies of Antennularia ramosa through 50 mesh, and placed in finger-bowls of Berkefeld water, 4 p.m. The temperature of the Laboratory is so high that these bowls were placed in a trough of running water.

1st February. Lobate masses, 1 to $2 \mathrm{~mm}$. in length, surrounded by perisarc have formed.

2nd. The lobes have further contracted, and most of the masses are attached to the glass.

2nd to 11th. Very little change observable except slight contraction by which a space was left between the contents and the perisarc. Clearer spaces appeared also in the body of the mass.

20th. One mass now 20 days old and thoroughly healthy in appearance fixed.

21st. Several small masses still alive. In the largest of them contraction of the contents at various points has resulted in a markedly spongy appearance, as shown in the figure. This is observable in a less degree in other smaller masses.

9th March. All remained alive up to this date, and without any apparent change. From this date onward the contents appear to be gradually degenerating-in one or two of the masses the enclosing perisarc is almost empty.

21st. The spongy appearance of the large mass is gradually changing, and the contents appear to be concentrating in the centre. This culture is now 51 days old, and has still a healthy yellow colour. Similar concentration has taken place in one or two of the smaller masses which were fixed for examination.

Experiment 23.-1st March, 1912, 11 a.m. Squeezed fine colonies of Antennularia ramosa through 50 mesh. Aggregation of cells commenced almost immediately.

3rd. Of the three cultures made on the 1st, two are not healthy. Spherical masses have formed, but they look soft and flocculent, and the perisare is not clear and smooth.

The third culture, however, has resulted in a healthy lobed mass, not attached to the glass-deep yellow in colour and with a smooth perisarc. The edges of this mass are folded over into knobbed ridges, round a thinner central plate. There is a nearly vertical cylindrical mass at one end. 
13th. The edges have curled over more, and ten knobs on them are more accentuated. The centre plate thinner, and at points clear spaces appear.

15th. Cut off the end of the vertical projection.

16th. Perisare had reformed round the cut end and the incised piece.

\section{SUMMARY AND CONCLUSION.}

1. The Hydroids experimented on were Antennularia ramosa, and $A$. antennina.

2. These were cut in pieces and pressed through bolting silk, with the result that isolated cells and small cell aggregates were obtained, which soon aggregated together to form compact masses.

3. These restitution masses secreted a perisarc within from 12 to 18 hours.

4. Various changes in shape, and general retraction of the mass away from the perisarc occurred later, but even up to 60 days there was no sign of the regeneration of the hydranths.

5. The restitution masses consisted of ectoderm and endoderm cells, and in addition such structures as nematocysts, ova, and broken down cells, all of which were subsequently absorbed and played no part in the future development. The ectoderm cells were relatively little damaged, and were embedded in a plasmodial mass formed by the endoderm cells.

6. A definite layer of ectoderm cells is formed on the surface, and these cells secrete the perisarc.

7. Gradual aggregation and segregation of the endoderm cells from the plasmodial mass takes place; and they form very definite tubules similar in structure to the cœnosarcal tubules continuous with the enteric cavities of the normal hydranths. These tubules are embedded in a mass of ectoderm cells, they are convoluted and ramify in all directions. Many granules develop in the cytoplasm of these cells, and after about a month many of them have degenerated.

8. The ectodermal cells show no signs of degeneration, and the masses containing them have been kept alive for 60 days at the time of writing.

9. In none of the experiments was there any sign of the occurrence of cell division. 
In conclusion, we can say that, experimenting on different species of Hydroids to those employed by Wilson, we have confirmed his results up to the stage of development at which the restitution mass is formed and the perisarc secreted. Beyond that our results differ; in the species used by Wilson the restitution masses soon gave rise to hydranths, and practically complete new Hydroids were regenerated; in the species of Antennularia used by us development of the restitution masses was much slower ; they never regenerated hydranths, but gave rise to tumourlike masses of convoluted tubules lined with endodermal cells embedded in masses of irregularly arranged ectoderm cells. These masses remained alive for at least 60 days.

Our experiments have resulted in the production of masses that are certainly abnormal and pathological, but nevertheless we would submit that the segregation and rearrangement of the cells after isolation, and the comparatively long duration of life of the tumour-like masses to which they give rise are facts of considerable theoretical interest.

Plymouth,

March 28th, 1912. 


\title{
On $F_{2}$ Echinus Hybrids.
}

\author{
By
}

H. M. Fuchs.

AN investigation on inheritance in hybrids between the three English species of Echinus was carried out in the Marine Biological Laboratory, Plymouth, during 1909-1912 by C. Shearer, W. de Morgan, and H. M. Fuchs. In a paper published in the Phil. Trans. Royal Soc., Ser. B, Vol. CCIV., p. 255, the results of this work were described in detail. At the time of publication, E. miliaris had been raised from the egg to maturity in the laboratory, in the course of one year, and a second generation had been obtained from these individuals, but none of the hybrid urchins had as yet reached maturity. This year, however, some of the hybrids have become sexually mature, and from them a second hybrid generation has been raised.

The urchins which have formed ripe genital products are four individuals of the cross $E$. esculentus + X E. acutus $\delta$ (referred to below as $E A$ ), derived from fertilizations made in 1912. The largest of these urchins now measures $6 \mathrm{~cm}$. in diameter, exclusive of the spines. On May 11th, 1914, two of these hybrids laid eggs in the tank in which they were kept. Naturally these eggs could not be used for experimental purposes, since they were deposited in the sea-water of the aquarium circulation, and therefore not under sterile conditions. On June 6th I induced three of the four to deposit genital products without cutting them open, under conditions which excluded the possible presence of foreign eggs or spermatozoa. It is hardly recessary to mention here that, as in all the previous work on Echinus hybrids, the fact of the complete absence of such sperm was made certain by controls of unfertilized eggs, none of which segmented. Two of the three hybrids from which genital products were obtained proved to be females and one a male. The sperm from the latter gave $100 \%$ fertilizations with the eggs of the former, yielding healthy larvæ.

From this it is seen that hybrids between the species $E$. esculentus and E. acutus are perfectly fertile and that a healthy $\mathrm{F}_{2}$ generation can be obtained from them. When a larger number of these $\mathrm{F}_{1}$ hybrids have been 
reared, an examination of the characters of the fully grown urchins should decide whether the intermediate forms between the two species, which are found in the sea and which are quite fertile, are to be considered as hybrids or as extreme variants of one of the two species.

Besides making the cultures described above, I fertilized $E$. mitiaris eggs with the sperm of the $E A$ male, and used $E$. mitiaris sperm to fertilize $E A$ eggs. This was done in order to see whether the inheritance of the late larval characters (posterior epaulettes and green pigment) in these crosses would be the same as when pure $E$. esculentus or $E$. acutus was crossed with $E$. miliaris. Now, twenty-one cultures, * derived from fifteen fertilizations, have shown that the inheritance of these larval characters has this year been the same as it was in 1912: the E. esculentus or $E$. acutus characters are developed in the hybrids in both reciprocal crosses with $E$. mitiaris. It was found that the two reciprocal combinations of $E A \mathrm{X}$ mitiaris likewise gave this result. From the cross $E A \subsetneq \mathrm{X}$ mitiaris o large numbers of vigorous fully formed plutei de. veloped, and a number of these "triple-hybrids" have already passed through metamorphosis.

Unfortunately the $\mathrm{F}_{2}$ generation obtained from the $E$. esculentus $\mathrm{X}$ $E$. acutus hybrids can give no information as to the inheritance of the late larval characters, since the latter are alike in the two species. It is the $\mathrm{F}_{2}$ generation from hybrids between $E$. esculentus or $E$. acutus and E. mitiaris that will give this valuable information, but none of these hybrids have as yet reached maturity. A small number of $E$. miliaris $q$ $\mathrm{X} E$. acutus o hybrids (of which the largest measured $2 \frac{1}{4} \mathrm{~cm}$. in diameter, exclusive of spines), from fertilizations made in May, 1912, were alive and healthy this summer. After having tried unsuccessfully to induce these to deposit eggs or sperm, I cut them open on June 6th of this year. They contained, however, only small and quite immature gonads.

As it must be some time before more $E$. acutus (or F. esculentus) X $E$. mitiaris hybrids will have grown large enough to be mature, I wish to record these results up to date. The success in bringing the $E A$ hybrids to maturity has been largely due to the care taken by Mr. A. J. Smith, head assistant at the Plymouth Laboratory, in attending to the cultures after metamorphosis. The investigation was made with the assistance of a grant from the Royal Society.

\footnotetext{
* Some of these cultures were reared at Plymouth, others were transported as blastulæ to the Imperial College, London, and raised there in water which came from Lowestoft.
} 